\title{
DOMINANT IDEAS OF FINANCIAL TECHNOLOGIES IN DIGITAL BANKING
}

\author{
Svitlana Melnychenko ${ }^{1}$, Svitlana Volosovych ${ }^{2}$, Yurii Baraniuk ${ }^{3}$
}

\begin{abstract}
The purpose of the research is the definition of the dominant ideas of financial technologies in digital banking. The methods of theoretical generalization, qualitative, quantitative and correlation analysis, causality tests, description and explanation are used, which made it possible to establish the relationship between the volume of investments in financial technologies and the performance of the banking system, identify the areas of application of financial technologies in the activities of the bank, determine the dominant ideas of financial technologies in digital banking and to uncover the factors and prospects of intensifying the use of financial technologies in digital banking in Ukraine. Results of the research are to substantiate the impact of artificial intelligence, biometrics, cloud services, big data, blockchain and open banking services on digital banking. Due to financial technologies in digital banking, it is possible to generate and store large amounts of data, simultaneously analyze and apply the results of their analysis, provide personalized banking services, perform the functions of central storage of information about the client of financial and non-financial nature, which facilitates the effective investment and credit decision-making, as well as improving the level of information security of banking operations. Practical implications. Financial services markets are transformed by the impact of financial technologies. Development of financial technology instruments by non-banking institutions necessitates the identification of opportunities for their use in banks. The set of financial technologies used by banks forms the digital banking system, the development level of which is the main competitive advantage of the bank in the business environment. Digital banking is characterized by the continuity and security of banking services, which provide the consumer with the ability to receive them online anywhere around the clock, personalization of banking services, digital authentication of users and digitization of banking transactions with the replacement of paperwork. The use of financial technologies in digital banking enables to automate customer segmentation processes, reduce costs on payment transactions, optimize accounting, financial and tax accounting, improve customer service and expand your customer base while maximizing revenue in certain business segments. Value/originality. The basic spheres of the use of financial technologies in digital banking, as well as the factors and prospects of intensifying the use of their instruments in Ukraine are revealed. The main areas of use of financial technologies in digital banking are customer behavior analysis, transaction monitoring, customer identification and segmentation, fraud management, banking services personification, risk assessment and regulatory compliance, customer response analysis, process automation, financial advice, investment decision-making, trade facilitation, syndicated loan services, and P2P transfers. The prospects for developing financial technology tools in digital banking include strengthening the interaction between regulators, banks and financial technology companies, the increased use of biometrics, the development of neo-banking and open banking services.
\end{abstract}

Key words: digital banking, financial technologies, cloud services, blockchain, big data, artificial intelligence, biometrics.

\section{JEL Classification: G21, 014, O32, Q55}

\footnotetext{
Corresponding author:

${ }^{1}$ Kyiv National University of Trade and Economics, Ukraine.

E-mail: melnichenko@knteu.kiev.ua

ORCID: https://orcid.org/0000-0002-5162-6324

ResearcherID: N-9535-2016

${ }^{2}$ Kyiv National University of Trade and Economics, Ukraine.

E-mail: volosovich_sv@ukr.net

ORCID: https://orcid.org/0000-0003-3143-7582

ResearcherID: N-2394-2016

${ }^{3}$ Kyiv National University of Trade and Economics, Ukraine.

E-mail: baraniukyurii@gmail.com

ORCID: https://orcid.org/0000-0003-1289-2248

ResearcherID: J-5726-2018
} 


\section{Introduction}

Financial services markets are transformed by the impact of financial technologies. In recent years, there has been a situation in the European countries where financial institutions are empowering consumers to access cheaper products, lowering fees for intermediaries, which increases competition between them. The result of competition in the banking sector is the formation of conditions under which in some countries deposit interest rates have acquired negative values in the currencies of Euro, Swiss Franc, Japanese Yen, etc. These effects lead to a decrease in profitability of banking institutions, decreases the margin between interest rates on credit and deposit products, business and households saving more funds directs to consumption. To maintain market positions, banks develop collaborations with non-banking institutions to develop financial technology tools that can optimize individual business processes and help to improve customer service. As a result, there is a need to substantiate the impact of dominant ideas of financial technologies on the activities of banks, in particular, digital banking.

The purpose of the research is the definition of the dominant ideas of financial technologies in digital banking. Based on the stated purpose, the following research objectives are solved in the article:

- to establish the relationship between the volume of investments in financial technologies and the performance rates of the banking system;

- to identify areas of application of financial technologies in the bank's activities;

- to identify dominant ideas of financial technologies in digital banking and substantiate their feasibility;

- to reveal the factors and prospects of intensifying the use of financial technologies in digital banking in Ukraine.

The works of scientists and practitioners, published in Ukraine and abroad, became the scientific base of the research. The research was conducted using the methods of theoretical generalization, qualitative, quantitative and correlation analysis, causality tests, description and explanation. To identify the impact of financial technology investments on the volume of bank loans and deposits in the European Union countries, the materials of the European Statistical Office and the auditing company KPMG International were used.

\section{Literature review on the definition of the essence of digital banking in the conditions of development of financial technologies}

Financial systems undergo transformational changes, which are a characteristic feature of the economic systems of many developed countries (Mazaraki, 2018). As Melnyk T. (2019) points out, significant transformations of the structure of the financial system are caused both by the invention of new financial instruments and the gradual process of universalisation of banking activities.

The reliability, financial firmness, efficiency of the bank's operation and its competitiveness in the market depend on the introduction of innovative banking products and technologies that can be an impetus in the further development of the banking system as a whole (Rysin, Fediuk, 2017). In the context of the transformation of the domestic economy towards the transformation of consumer preferences and technological solutions (Mazaraki, Kasianova, 2015; Baranovskyi, 2018), banking institutions are influenced by their activities such as increasing the need to take into account the dynamic needs of consumers, increasing the cost of financial technology products, increased competition from a growing number of non-traditional banking service providers, and increased demands from central banks (Mnykh, Bardash, Shevchuk, 2011).

Back in 2015, A. Jenkins, CEO of Barclays, one of the UK's largest banks, suggested that the introduction of financial technology into the banking service delivery process could cut half the staff of large banks, which is necessary because of the decline in banking profitability in individual regions (Williams-Grut, 2015). It follows that the use of financial technologies in the banking sector is now a necessary component of the banking institution's ability to survive in the market. The set of financial technologies that are implemented in the activities of the bank, constitute a certain technological system, which means digital banking.

Digital banking is a new paradigm of customer-bank interaction as it is a field that embraces innovation in financial services for IT customers in the area of information and technology solutions (Hontar, 2017). At the same time, it is believed that digital banking is broader than the activity of an online platform or mobile banking, as it relates to the automation of every stage of a bank's relationship with a customer, which involves the digitization of both banking services and all banking and customer activities (Five Degrees Solutions, 2019). It follows that in the current context, the essence of digital banking is characterized by the continuity of banking services, which provide the consumer with the ability to receive them online anywhere around the clock, personalization of banking services, digital authentication of users and digitization of banking transactions with the replacement of paperwork.

There are three stages of the evolution of digital banking. The first stage concerned the introduction of ATMs and call centers into the banking activities, which improved customer service. In the second phase, cloud technologies, social networks, analytics and mobile access were applied, which allowed banking institutions to personalize their banking services. The third stage of development of digital banking is related to the use 
of artificial intelligence, blockchain, programming interfaces, robotization of individual business processes. In the third stage of development of digital banking the following components are distinguished:

1. Three-tier digital core banking architecture, including: presentation level; client level; product level.

2. Collaboration with other financial technologies, which presupposes the existence of a common system.

3. Customer trust and massive customer acquisition (Five Degrees Solutions, 2019).

Nowadays, the popularity of digital banking is growing all over the world. Thus, the results of the Visa survey indicate that $91 \%$ of the Turkish residents use mobile payments and online banking, $89 \%$ in Denmark, $87 \%$ in Norway; 86\% in Israel (Bainazarov, 2018).

According to a survey of the companies in North America and Europe in 2019 conducted by Bottomline Technologies, $76 \%$ of banks seek to maximize the use of financial technology solutions for payment services and do so in order to retain customers of certain segments, whereas $28 \%$ of corporations surveyed indicate that they use non-banking providers for payments. A survey finds that nearly half of corporations use or are interested in using new payment services, with the focus on real-time payments (55\%), automated clearing centers $(44 \%)$ and implementation of blockchain services (35\%) (The Paypers, 2019).

\section{Results}

\subsection{Influence of investments in financial technologies on the performance of the banking system}

The financial technology market of the world has shown rapid development in recent years, driven by the demand from leading international banks for innovative products and the supply of financial technology companies. For international banks, there is a need to automate business processes, create the conditions under which it is possible to expand the customer base, increase the demand for banking products, which contributes to the use of financial technology tools.

According to Ian Pollari, in the current conditions, the international financial market continues to expand and diversify. Geographically, there has been an increase in activity in the financial markets in Brazil, Japan and South Korea. Also, there is a diversification of financial technology sectors in the world, in particular, regtech (regulatory technology), wealthtech (wealth technology), insurtech (technology for insurance companies), proptech (real property technology). The diversification of financial technologies between countries and species in the near future will be able to strengthen the financial markets, including the banking segment (KPMG, 2019).

Financial sector institutions, including banks, are ready to invest resources in financial technology, the amount of which is increasing every year. An analysis of the continental geography of investing in financial technology shows that the greatest growth is demonstrated by the America and the countries of Europe (KPMG, 2019). The growth in investment in financial technology has enabled European banks to expand their operations, increase deposits and lending, as evidenced by statistics. The Granger causality test between the dynamics of investments in financial technologies (KPMG, 2018) and the volume of deposits and loans in Europe, by corporations, households, insurance, pension and other financial institutions (Euro area statistics, 2019), allowed to establish the relationship between the indicators under research. In particular, the following results were obtained:

- a decrease in deposits from insurance and pension companies led to an increase in investments in financial technology instruments (the Granger P-value $=0.0009$; the Pearson correlation coefficient $=-0.35881$ );

- an increase in investments in financial technology instruments led to an increase in lending to other financial corporations (the Granger P-value $=0.0225$; the Pearson correlation coefficient $=0.554475$ ) .

It follows that, on the one hand, the increase in investments in financial technologies in 2012-2018 is due to the outflow of resources of insurance companies and pension funds from the banking sector, their funds are placed in non-banking institutions, probably in bonds or specialized funds for asset management. On the other hand, the growth of investments in financial technologies, in the same period, broadens the horizons of cooperation of banks with other financial institutions, including the inter-bank one. For example, for a banking institution that trades in securities, there is a need to make payments on their purchase or sale transactions, which can be done with the help of depository service providers, there are only two of them in Europe (Clearstream, Euroclear). Therefore, in certain banking segments, the use of financial technologies is a prerequisite for the provision of services or transactions.

\subsection{Areas of application of financial technologies in the bank's activities}

In recent years, digital technologies such as big data, artificial intelligence, biometrics and blockchain have become widespread in digital banking. Previously, financial technology tools in the bank were used, as a rule, in the form of software for keeping accounts, transactions, managing customer databases, now they can be used in most banking operations (Table 1).

According to Table 1, the financial technologies in digital banking, depending on the area of application, can be divided into two groups, one of which is aimed at developing customer service, the other is to optimize the operation of internal systems. 
Table 1

Dominant ideas of financial technology in digital banking

\begin{tabular}{|l|c|c|c|}
\hline \multicolumn{1}{|c|}{ Area of application (dominant ideas) } & Big data & Artificial intelligence & Biometrics \\
\hline Analysis of customer behavior & + & + & - \\
\hline Transaction monitoring & + & + & - \\
\hline Customer segmentation & + & - & - \\
\hline Customer identification & + & + & + \\
\hline Fraud management & + & + & - \\
\hline Personalization of banking services & + & + & + \\
\hline Risk assessment and regulatory compliance & + & + & - \\
\hline Customer response analysis & - & + & - \\
\hline Process automation & + & + & - \\
\hline Providing financial advice & + & - & - \\
\hline Investment decision-making & - & - & - \\
\hline Trade facilitation & - & - & - \\
\hline Syndicated loan services & - & - & - \\
\hline P2P transfers & + & - & - \\
\hline
\end{tabular}

Source: complied by the authors

\subsection{Dominant financial technologies in digital banking}

Dominant financial technologies in digital banking aimed at developing customer service are artificial intelligence, biometrics and open banking services. Open banking should be understood as a set of rules that give users access to information from various financial institutions (banks, payment service providers, insurance companies) through application programming interfaces (Ifrim, 2019). The development of open banking creates new opportunities for both banks and consumers.

For banks, open banking allows to retain customers and increase product value through additional services. In the retail banking segment, open banking helps to eliminate the difficulties of registering new customers, creating personalized offers based on customer behavior. And in the retail segment, open banking allows to inform the customers about the balance, electronic receipts and transaction history.

For customers, the advantages of open banking are the ability to obtain financial management services, view their accounts at different banks in one place. Examples of consumer benefits include paying for taxi via the bank application P2P, purchasing a ticket with travel insurance, etc. For corporate clients, the open banking allows to manage liquidity, maintain accounting and tax records. The results of the 2018 Accenture Open Banking for Businesses survey indicate that $77 \%$ of corporations have already participated in, or plan to do, open-source platforms, mainly payments and cost management (Ifrim, 2019).

In recent years, artificial intelligence technology in customer service has become widespread in digital banking, enabling enhanced quality of service through personalized services, prevention of cybercrime and fraud.
Artificial intelligence is used:

- In 2018 Bank of America launched Erica, a virtual assistant, it uses predictive analytics and cognitive messaging to provide financial guidance to customers around the clock. Erica helps with balance information, transaction overview and payment planning. Customers communicate with Erica via voice or text messages;

- BBVA uses BBVA Valora to calculate the best price for renting, selling or buying a property, Home and Baby Planner help to understand how starting a family and having a baby will affect your financial situation. The bank also plans to launch a new program that uses biometric technology to automate payments, allowing users to book tables at restaurants, place orders from their smartphone and pay for food without requiring an account;

- Citibank has strategically invested in a leading information technology company, Feedzai, to alert customers of fraudulent actions in real time;

- JP Morgan Chase launched COiN platform in 2017 to avoid errors and reduce credit servicing time;

- The Royal Bank of Scotland uses an automated commercial real estate lending process worth up to $2.7 \mathrm{mln}$ USD in less than 45 minutes away, although it usually takes several days (W.UP, 2018).

The most common areas of artificial intelligence in banks include: customer information support, which involves directing them to the appropriate source of information and reducing the burden on bank employees; accumulation of customer data; carrying out of individual banking transactions by means of chatbots, in particular, opening or closing of an account, transfer of funds; the provision of services based on consumer behavior, which is analyzed through smart programs; providing advice to clients on managing their assets and spending through digital assistants; development of investment plans for clients based on real-time data from financial markets. 
An important technology used in working with clients in digital banking is biometrics. The fingerprint recognition, which was first applied in 2013 on Apple smartphones with Touch ID, has now caught the attention of most of the world's banks. Nowadays, contactless ATMs with the use of smartphone and biometrics are becoming more popular. Biometric ATM user authentication is already in place in India, Japan, China, and iris authentication in Qatar. Therefore, there are 80000 ATMs in Japan with biometric identification of more than 15 million customers. At the same time, in April 2017, the international payment corporation MasterCard Worldwide announced a biometric credit card (Thakkar, 2019). It is likely that next-generation ATMs with fingerprints will completely replace PIN-based ATMs.

According to the above, it follows that digital banking financial technologies aimed at developing customer service are artificial intelligence, biometrics and open banking services. The use of these financial technology tools helps to improve the quality of customer service and, consequently, to expand the customer base, while increasing the amount of revenue in the respective segment.

Dominant financial technologies in digital banking aimed at optimizing the operation of the internal systems of the bank are cloud technology, big data, blockchain and artificial intelligence. The role of big data technology for banks is continuing to grow. The use of big data technology in digital banking enables customer segmentation, which can save the marketing budget. As far as determining the position of the bank in the market, based on the available resources, will allow us to concentrate efforts and direct actions in the direction that will ensure the bank's acquisition of achievable market share, which will contribute to obtaining the desired result.

Big data technologies in digital banking are able to solve the problems of business process optimization and automation, which will allow banks, on the one hand, to save resources, and on the other hand, to reduce operational risks. However, the solution to this problem requires modern technology in banking institutions, as legacy systems will not be able to cope with the increasing workload, which requires increased capacity for processing information or complete system reconstruction.

With the help of big data technology in digital banking, it becomes possible to organize the system of "social listening", i.e. the analysis of information on user activity on social networks, to identify problems and correct them. Since Barclays launched the mobile app, many people have expressed dissatisfaction in social networks that users under the age of 18 have not been able to transfer or receive money. As a result, there was made a decision by Barclays management, after which users aged 16 and under were allowed to access the program.
The use of big data technology in digital banking necessitates the expansion of computer hardware memory. To address this, more and more banks are moving from traditional storage systems to the use of cloud storage. In April 2018, Microsoft told the daily newspaper The Financial Times that the key to successful implementation of cloud financial services is having a close partnership between regulators, financial institutions and cloud providers to provide the right structures, programs and processes that will leverage cloud services (Springfield, 2018).

The use of cloud technology in digital banking can reduce the cost of hardware, software and related workforce. It is easier for banks to upgrade their IT infrastructure against the backdrop of the fact that the cost of using online resources to save data provides significant cost savings. The availability of cloudbased technology tools in digital banking contributes to improving the efficiency of banking, since cloudbased standardization can facilitate the integration of new technologies in the future. Also, the use of cloud technology makes customer service fast as computing power grows, providing the departments involved with the solutions. The need for cloud technology is emerging at international banks as well, since it requires considerable additional costs to exchange information between regional and head offices, and access to the cloud enables users to share data anywhere in the world.

An important advantage of cloud technology in digital banking is the ability to scan over a thousand transactions per second, which greatly improves banks' ability to deal with financial crimes such as fraud and money laundering. At the same time, there is a need to constantly observe security measures to protect the data stored in the cloud, to guarantee the constant availability of programs and data in case of force majeure, effective management of clouds when receiving services from multiple providers, since it is necessary to ensure communication between all business processes and units, as well as with customers. This requires a single interface and management layer that can run across platforms inside and outside the cloud (FinTech Futures, 2014).

The recording and storage of data in banks is made possible by means of blockchain, which helps to optimize accounting, financial and tax accounting in the bank, as well as to automate the processes of issuing loans in the part of the verification of customer information. Blockchain in digital banking is capable of reducing the cost of settling investment banking activities. Thus, according to the results of the Accenture study, clearinghouses and payment systems can save about 10 bln USD annually when using blockchain technology (Binance, 2019). However, it should be kept in mind that the use of blockchain in digital banking is able to increase the speed of payment transactions, especially those performed between countries, due to the high speed of data exchange. 
One of the main problems in using financial technology tools in digital banking is to ensure the security of banking activities. Thus, $73 \%$ of the US banks recognized their security concerns as citing privacy issues as a major concern. Banks are losing resources every year as a result of fraud, with central banks increasing the pressure every year to protect customers' personal data. The EU General Data Protection Regulation, which came into force in May 2018, strengthened citizens' rights to data. According to expert estimates, the use of blockchain by banks in the field of personal data protection can save up to 1 bln USD of operating costs and reduce penalties by 2-3 bln USD (Debonis, 2017).

The need for reliable and fast processing of large amounts of data, the emergence of mobile technologies, data availability and the distribution of open source software create the basis for enhancing the use of artificial intelligence in digital banking. Using artificial intelligence technology, it becomes possible to carry out credit risk assessments that require accuracy and confidentiality. In doing so, there is an opportunity to minimize the likelihood of errors and fraud.

Accordingly, financial technology tools in digital banking aimed at optimizing the operation of the bank's internal systems are cloud technologies, big data, blockchain and artificial intelligence, while the use of some of them also helps to improve customer service.

According to a study conducted by the international payment company Mastercard Worldwide, $87 \%$ of the polled representatives of the banking sector in Ukraine are ready to partner with FinTech startups (UNIT. City, 2018). In 2017, the first domestic digital bank Monobank was launched in Ukraine, where individual customers can receive payment, deposit and credit services through the mobile application.

\subsection{Factors and prospects of intensifying the use of financial technologies in digital banking in Ukraine}

Digital banking in Ukraine has seen an increase in the use of financial technology tools. The main factors influencing the intensifying the use of financial technologies in digital banking in Ukraine are:

- changes in the domestic regulatory framework that contribute to the development of financial technologies, in particular, the granting of authorization to sign accounts and agreements by electronic signature, Ukrainian financial technology companies continue to use simplified taxation of $5 \%$ per year, adoption of the law on electronic identification;

- access to capital and investment, in particular the abolition of the requirement for Foreign Direct Investments;

- sufficient readiness of the domestic financial technology market. In particular, $40 \%$ of financial technology providers were established by 2015 (UNIT. City, 2018).
Considering the distinguished factors, it should be noted that the prospects for the development of financial technologies in digital banking in Ukraine are:

1. Development of neobanks that serve consumers through the use of sites and mobile applications without having physical offices in them. These banks are now popular in the US and the UK. Neobanks offer services such as deposit accounts, payment services, money transfers, loans to individuals and business entities.

2. Intensifying the open banking development through the Directive PSD2, which provides access to the data of more than 5000 European banks.

3. More use of biometrics in digital banking. Banks are increasingly using biometric customer identification when providing services through a mobile device, as they have a higher level of security than passwords, PINs or e-mails that are highly likely to be hacked.

4. Increasing the interaction between regulators and financial technology companies. According to the statement of the National Bank of Ukraine, it is planned to create a platform for communication with financial technology companies to assess the volumes and needs of this market (National Bank of Ukraine, 2018).

5. Strengthening the interaction between banks and financial technology companies. According to the survey of 39 banks in 17 countries conducted by PricewaterhouseCoopers, it was found that future partnerships with financial sector companies are important for $92 \%$ of banks (Scheele, 2018). As a result, the rapid development of the digital economy now has a significant effect on the fact that banks have more and more business partners in the financial technology sector every year.

\section{Discussion}

Thus, digital banking involves digitization based on the use of financial technology tools in the processes of banking services, banking operations or the operation of bank information systems.

Its strengths are the ability to generate and store large amounts of data while simultaneously analyzing and applying the results of their analysis. Also, the strengths of the use of financial technology tools in digital banking include the impartiality of decision-making, i.e. those decisions that are less dependent on staff, the ability to provide personalized banking services to clients, the functions of central repository of financial and nonfinancial customer information.

The disadvantages of using financial technologies in digital banking are that their presence contributes to the development of non-banking financial institutions, which leads to a decline in the pace of development of traditional banks. A major drawback to consider is the lack of licensing of financial technology companies, which leads to their failure to comply with regulatory requirements in the field of digital banking. 
Threats to use financial technologies in digital banking are to reduce the number of bank employees, create new risks through automated systems, in particular, the risks of falsification, external manipulation of data.

The potential of using financial technology tools in digital banking is to make effective investment decisions, increase the level of information security of operations, strengthen the cooperation of banks and companies in the financial technology sector.

\section{Conclusions}

The development of the financial technology market tends to expand and diversify. Geographically, there is an increase in activity in the financial markets in the Americas and Europe. However, there is a diversification of financial technology sectors, with regtech, insurtech, wealthtech and proptech emerging. This diversification between countries and products helps to strengthen the financial markets, including the banking segment.

The trend of investments in the financial technology market shows an increase in the period of 2012-2018. Increasing investment in financial technology allows the European banks to expand their operations, increase deposits and lending. The catalyst for accelerating the growth of investments in financial technology is the decline in bank deposits from insurance and pension companies. Due to the growing volume of investments in financial technology, the European banks have been able to increase lending to other financial corporations, including banks among themselves.

The use of financial technology is taking place in digital banking, which is a field that covers the bank's innovation in information and technology solutions. Moreover, digital banking concerns the automation of both banking services and all banking activities. The digital banking is characterized by the continuity of banking services, which provide the consumer with the ability to receive them online anywhere around the clock, personalization of banking services, digital authentication of users and digitization of banking transactions with the replacement of paperwork.
The main areas of use offinancial technologies in digital banking are customer behavior analysis, transaction monitoring, customer identification and segmentation, fraud management, banking services personification, risk assessment and regulatory compliance, customer response analysis, process automation, financial advice, investment decision-making, syndicated loan services, trade facilitation and P2P transfers. Depending on the scope of use of financial technology tools, they can be divided into two groups, one of which is aimed at the development of customer service, the other is to optimize the operation of internal systems.

Dominant financial technologies in digital banking aimed at developing customer service are artificial intelligence, biometrics and open banking services. The use of these financial technology tools helps to improve the quality of customer service and, consequently, to expand the customer base, while increasing the amount of revenue in the respective segment.

Dominant financial technology tools in digital banking aimed at optimizing the operation of the bank's internal systems are cloud technologies, big data, blockchain and artificial intelligence, while the use of some of them also helps to improve customer service. The need to use certain financial technology tools in digital banking is that they help to create personalized banking products, automate the processes of issuing loans in terms of verifying customer information, segment customers, reduce the cost of settlements in investment banking, optimization of accounting, financial and tax accounting in the bank.

Factors of intensification of the use of financial technology instruments in digital banking in Ukraine are changes in the domestic regulatory framework, creation of opportunities for foreign investment and sufficient maturity of the national market of financial technologies. The prospects for developing financial technology tools in digital banking include strengthening the interaction between regulators, banks and financial technology companies, the increased use of biometrics, the development of neo-banking and open banking services.

\section{References:}

Bainazarov, N. (2018). Tsyfrovoi bankynh - cheho my ozhydaly y chto my poluchyly [Digital banking - what we expected and what we got]. Rusbase. Retrieved from: https://rb.ru/story/banking-v-cifre (accessed 21 November 2019).

Baranovskyi, O. (2018). Yakist transformatsiinykh protsesiv u finansovomu sektori natsionalnoi ekonomiky: vektory vymiru [The quality of transformation processes in the financial sector of the national economy: measurement vectors]. Finansovo-kredytna diialnist: problemy teorii ta praktyky, 3(26), 350-367. (in Ukrainian)

Binance (2019). 10 ways blockchain improves banks. Retrieved from: https://www.binance.com/en/ blog/317964880487174144/10-Ways-Blockchain-Improves-Banks-and-Makes-Them-Less-Important (accessed 21 November 2019).

Debonis, J. (2017). Banking on the cloud: why banks should embrace cloud technology. Bankdirector. Retrieved from: https://www.bankdirector.com/issues/technology/banking-cloud-banks-embrace-cloud-technology (accessed 21 November 2019).

Euro area statistics (2019). Banks balance sheet. Retrieved from: https://www.euro-area-statistics.org/banksbalance-sheet-loans? cr=eur\&lg=en\&page $=0 \&$ charts $=$ M..N.A.A20.A.1.U2.2250.Z01.E+M..N.A.A20.A.1.U2. 2240.Z01.E+M..N.A.A20.A.1.U2.2220.Z01.E\&template $=1$ (accessed 21 November 2019). 
FinTech Futures (2014). Six reasons why cloud computing will transform the way banks serve clients - and the five hurdles to overcome. Retrieved from: https://www.bankingtech.com/2014/07/six-reasons-why-cloudcomputing-will-transform-the-way-banks-serve-clients-and-the-five-hurdles-to-overcome (accessed 21 November 2019).

Five Degrees Solutions (2019). Digital banking: anywhere and anytime. Retrieved from: https://www.fivedegrees.com/ digital-banking/what-is-digital-banking (accessed 21 November 2019).

Hontar, A. (2017). Tsyfrovoi bankynh kak odna yz sostavliaiushchykh эkonomycheskoi bezopasnosty kredytnoi orhanyzatsyy [Digital banking as one of the components of the economic security of a credit institution]. Vestnyk Volzhskoho unyversyteta ymeny Tamyshcheva, 4, 1-8. (in Russian)

Ifrim, O. (2019). Open Banking is flashing bright - what problems can it solve? The Paypers. Retrieved from: https://www.thepaypers.com/expert-opinion/open-banking-is-flashing-bright-what-problems-can-it-solve-/ 778758 ? utm campaign $=20190515$-automatic-newsletter\&utm medium $=$ email\&utm source $=$ newsletter $\&$ utm_content (accessed 21 November 2019).

KPMG (2019). The pulse of Fintech 2018, end-of-year edition. Retrieved from: https://assets.kpmg/content/ $\mathrm{dam} / \mathrm{kpmg} / \mathrm{xx} / \mathrm{pdf} / 2019 / 02 /$ the-pulse-of-fintech-2018.pdf (accessed 21 November 2019).

KPMG (2018). The pulse of Fintech. Biannual global analysis of investment in Fintech. Retrieved from: https://assets.kpmg/content/dam/kpmg/xx/pdf/2018/07/h1-2018-pulse-of-fintech.pdf (accessed 21 November 2019).

Mazaraki, A., \& Kasianova, A. (2015). Overview of proactive and reactive activities in corporate crisis management. Economic Annals-XXI, 3-4(1), 42-45.

Mazaraki A., Melnichenko S., Duginets G. et al. (2018). Ukrainian economy growth imperatives: monograph. Edited by Anatolii A. Mazaraki. Prague: Coretex CZ SE. 310.

Melnyk T., Melnychenko S., \& Reznikova N. (2019). The conceptual framework for the operation of financial systems in the context of global structural transformations of business models of banking. Baltic Journal of Economic Studies, 5(4), 148-154. doi: 10.30525/2256-0742/2019-5-4-148-154

Mnykh, Ye., Bardash, S., \& Shevchuk, O. (2011). Kontrol u sferi innovatsiinoho menedzhmentu pidpryiemstva: monohrafiia [Control in the field of enterprise innovation management]. Kyiv: Kyivskyi natsionalnyi torhovelnoekonomichnyi universytet. (in Ukrainian)

National Bank of Ukraine (2018). Didzhytalizatsiia finansovykh posluh [Digitization of financial services]. Facebook news. Retrieved from: https://www.facebook.com/NationalBankOfUkraine/posts/2177028069178020 (accessed 21 November 2019).

Rysin, M. \& Fediuk, I. (2017). Shliakhy vprovadzhennia innovatsiinykh bankivskykh produktiv v umovakh hlobalizatsii [Ways to introduce innovative banking products in the context of globalization]. Visnyk Universytetu bankivskoi spravy - Bulletin of the University of Banking, 3(30), 71-76. (in Ukrainian)

Scheele, J. (2018). Addressing cybersecurity in financial institutions/fintech partnerships. GlobalSign Blog. Retrieved from: https://www.globalsign.com/en/blog/addressing-cybersecurity-in-financial-institution-fintechpartnerships (accessed 21 November 2019).

Springfield, C. (2018). The impact of cloud computing on the banking sector. International Banker. Retrieved from: https://internationalbanker.com/banking/the-impact-of-cloud-computing-on-the-banking-sector (accessed 21 November 2019).

Thakkar, D. (2019). Using biometric authentication for customer verification (KYC). Bayometric. Retrieved from: https://www.bayometric.com/biometric-authentication-customer-verification-kyc (accessed 21 November 2019).

The Paypers (2019). Fintech gaining favour in B2B payments. Retrieved from: https://www.thepaypers.com/ e-invoicing-scf-e-procurement/fintech-gaining-favour-in-b2b-payments-bottomline-survey-finds/77891024?utm_campaign=20190524-automatic-newsletter\&utm_medium =email\&utm_source =newsletter\&utm content Taccessed 21 November 2019).

UNIT.City (2018). FinTekh v Ukraini [FinTech in Ukraine]. USAID Project: «Transforming the Financial Sector in Ukraine». Retrieved from: https://data.unit.city/fintech/fgt34ko67mok/fintech_in_Ukraine_2018_ua.pdf (accessed 21 November 2019).

Williams-Grut, O. (2015). Ex-Barclays CEO: Banks are about to have an 'Uber moment' - and it's going to be painful. Business insider. Retrieved from: http://uk.businessinsider.com/ex-barclays-boss-anthony-jenkins-onfintech-and-bankings-uber-moment-2015-11 (accessed 21 November 2019).

W.UP (2018). Machine learning in banking: the rise of the bots. Retrieved from: https://wup.digital/blog/ machine-learning-digital-banking (accessed 21 November 2019). 